\title{
Use of Thermally Assisted Hydrolysis and Methylation (THM-GC-MS) to Unravel Influence of Pottery Production and Post-Depositional Processes on the Molecular Composition of Organic Matter in Sherds from a Complex Coastal Settlement
}

\author{
Joeri Kaal $^{1, *(\mathbb{D})}$, María Guadalupe Castro González ${ }^{2} \mathbb{D}$, Antonio Martínez Cortizas ${ }^{3}$ (D) \\ and María Pilar Prieto Martínez ${ }^{2}$ \\ 1 Pyrolyscience, 15706 Santiago de Compostela, Spain \\ 2 EcoPast (GI-1553), Faculty of Geography and History, University of Santiago de Compostela, \\ 15703 Santigo de Compostela, Spain; guadalupe.castro@usc.es (M.G.C.G.); pilar.prieto@usc.es (M.P.P.M.) \\ 3 EcoPast (GI-1553), Faculty of Biology, University of Santiago de Compostela, \\ 15782 Santiago de Compostela, Spain; antonio.martinez.cortizas@usc.es \\ * Correspondence: joeri@pyrolyscience.com
}

check for updates

Citation: Kaal, J.; Castro González, M.G.; Martínez Cortizas, A.; Prieto Martínez, M.P. Use of Thermally Assisted Hydrolysis and Methylation (THM-GC-MS) to Unravel Influence of Pottery Production and

Post-Depositional Processes on the Molecular Composition of Organic Matter in Sherds from a Complex Coastal Settlement. Separations 2021, 8, 140. https://doi.org/10.3390/ separations 8090140

Academic Editor: Didier Thiébaut

Received: 3 August 2021

Accepted: 30 August 2021

Published: 1 September 2021

Publisher's Note: MDPI stays neutral with regard to jurisdictional claims in published maps and institutional affiliations.

Copyright: (c) 2021 by the authors. Licensee MDPI, Basel, Switzerland. This article is an open access article distributed under the terms and conditions of the Creative Commons Attribution (CC BY) license (https:/ / creativecommons.org/licenses/by/ $4.0 /)$.

\begin{abstract}
Ceramic fragments from the Islet of Guidoiro Areoso (NW Spain), covering a wide range of cultural periods (Neolithic to Late Bronze Age), have been studied by color analysis, elemental analysis of carbon (C) and nitrogen $(\mathrm{N})$, and molecular analysis (thermally assisted hydrolysis and methylation, THM-GC-MS), in order to identify the organic matter (OM) in the prehistoric pottery and reveal information on ceramic production techniques, food remains and post-depositional effects. Results showed that the strong marine influence (sherds recovered from coastal deposits) and microbial activity (recovery from waste deposits, "cuncheiros") had a profound effect on C/N ratio and molecular composition ( $\mathrm{N}$-rich protein and chitin structures). Other organic ingredients originated from the material used for creating the ware (detected as pyrogenic OM) and possibly food remains (fatty acid fingerprints). Dark-colored ware was enriched in both pyrogenic OM from incomplete combustion and non-bacterial fatty acids. Fatty acid patterns could not be related to possible vessel use, and markers of aquatic resources were scarce, or absent. It is argued that THMGC-MS of pottery fragments is useful for understanding how an archaeological deposit developed in time, what kinds of OM are present, and possibly to make a pre-selection of samples with high potential for more cost-demanding dietary molecular assessments.
\end{abstract}

Keywords: ceramics; molecular characterization; analytical pyrolysis; THM-GC-MS; color analysis; organic matter; coastal settlement; marine environment

\section{Introduction}

In spite of the advances in organic chemistry applications for archaeometry, there is still potential to be explored. Molecular research on organic constituents in ceramic materials have traditionally focused on total lipid extracts, aiming to characterize the preserved food residues, for instance by biomarker analysis (liquid and gas chromatography (GC) coupled to mass spectrometry (MS), such as GC-MS) [1-4] or compound-specific isotope ratio MS of lipid extracts from ceramic fragments [5,6], to obtain invaluable dietary information. However, recovered ceramic fragments contain organic matter (OM) from a wide range of possible sources, namely (1) the raw material clay fabric (incomplete burn-off during firing), (2) organic tempers and binders (incomplete burn-off), (3) soot deposited into or onto the ceramic during firing or during use (cooking), (4) decoration and finishing materials (varnishes, pigments, etc.), (5) use (food) residues, (6) post-use accumulations from the burial environment (soil OM, dissolved OM), (7) contamination from handling during excavation or laboratory treatments [7-9]. Identification and characterization of 
these sources of OM can reveal information related to ware production parameters (material selection, firing conditions) and vessel use, and therewith assist in the contextualization of pottery fragments. Many of the OM ingredients are macromolecular in nature and cannot be identified by means of molecular analyses of solvent extracts and require chemical or thermal treatment before identification [10].

Analytical pyrolysis techniques are frequently applied for the characterization of nonextractable OM in archaeological artifacts [11]. It has been used to identify paint ingredients, characterize jewelry or organic inclusions therein (resins, wooden artifacts etc.), identify animal tissues (hair, bone collagen, etc.), among others [12-17]. It has significant drawbacks, such as quantitative weakness, secondary reactions, loss of diagnostic features [18] and poor detection of ingredients that are present in trace concentrations. Therefore, analytical pyrolysis has significant limitations for the analysis of ceramics, especially for ingredients of low abundance relative to total OM such as food remains [19]. On the other hand, it has a strong capacity to provide a general screening of organic constituents that can be present, such as soot, charred temper, food residues and OM from the burial environment. Conventional analytical pyrolysis (Py-GC-MS) has been applied to archaeological potsherds with some frequency (e.g., [10,20-23]). Kaal et al. [20] performed statistical data evaluation of Py-GC-MS fingerprints of 24 ceramic samples from various settlements in NW Spain and compared the results with those from color and elemental analyses. Another pyrolysis method is thermally assisted hydrolysis and methylation THM-GC-MS [24], in which a reagent such as tetramethylammonium hydroxide (TMAH) is added to protect polar functional groups against pyrolytic degradation and improve their chromatographic separation [24]. THM-GC-MS has not often been used for ceramic material analysis in general. Shoda et al. [25] recently reported THM-GC-MS data of Neolithic pottery from Korea, using $\omega$-(o-alkylphenyl) alkanoic acids, isoprenoid fatty acids and triterpenoids as biomarkers of palaeodiet and in particular aquatic resources. Inspired by these results, we aimed to explore the potential of THM-GC-MS for the characterization of OM in a series of well-characterized ceramics recovered from Guidoiro Areoso islet in Galicia (NW Spain). This settlement is suitable as it contains ware from various cultural periods. In addition, being close to the (actual) see level, this set of ceramics has an added complexity of strong marine influences, reflected by for instance mollusks growing on potsherd surfaces. In addition, such coastal environments may be more likely to contain residues of aquatic resources that produce isoprenoid fatty acids [25-27].

The present study explores 50 samples analyzed by THM-GC-MS, color analysis and elemental analysis to determine the amounts of carbon $(\mathrm{C})$ and nitrogen $(\mathrm{N})$. The objective was to identify and characterize different OM components and link their abundances with pottery production, use and burial conditions. This study's novelty resides not only in the fact that a reasonably large number of potsherds are studied using THM-GC-MS and statistical data evaluation, but also in the unique marine-influenced environment from which the vessels were collected.

\section{Materials and Methods}

\subsection{The Site}

The settlement of origin of the ceramics is the megalith "Mámoa Nr. 4" (M4) of Guidoiro Areoso islet (Illa de Arousa, Pontevedra, NW Spain; Figure 1), excavated in 2017. It has a long record of ritual activity, at least from the Middle Neolithic to the Late Bronze Age, divided in five chronological periods [28]. Different forms of burial have been recorded, i.e., megaliths and a cist necropolis [29]. The megalithic activity is subdivided in Middle Neolithic, with many lithic and other artifacts yet ceramics are scarce, and Late Neolithic (bone remains, grave goods) with more fragments. The megalithic funerary activity then ends (stones placed to block entry) and the mound changed in function, becoming some kind of a shell waste deposit ("cuncheiro", or midden), probably related to a ceremonial role (including banquettes/feasts), from the final Late Neolithic stage to the Middle Bronze Age. At the first moment of activity in the midden, Penha and Bell 
Beaker Imitation type wares [30] were recovered. This kind of pots are related to Late Neolithic chronologies. The Early Bronze Age is mainly represented by different types of Bell Beaker pottery (undecorated Bell Beakers and some of the regional variations of the Bell Beaker pottery for Galicia [31]). The heterogeneity of Early Bronze Age pottery suggests several moments of activity along this period. During the Middle Bronze Age the midden continues to grow in all directions, containing many in situ potsherds. Then, at the beginning of Late Bronze Age (Late Bronze Age I), ceremonial activities related to the midden halted, and the midden was buried by sediment. On this new soil surface, large ware had been placed on top. Finally, during the Late Bronze Age II, different structures were built on the mounds. Stones, cists, millstones and typical Late Bronze Age pottery were found.
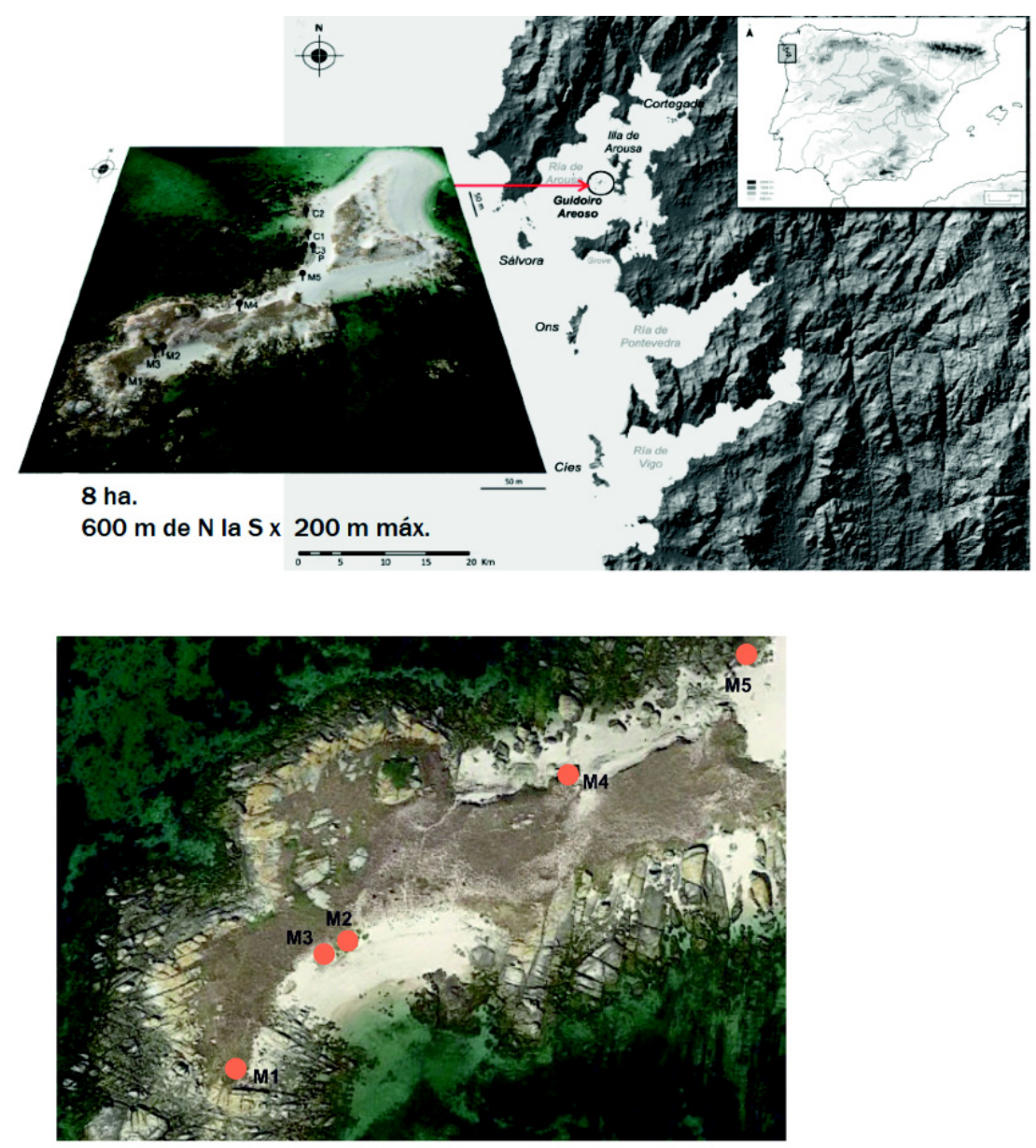

$60 \mathrm{~m}$

Figure 1. Location of the Guidoiro Areoso islet in the Ría de Arousa (modified after [32]).

\subsection{Sample Selection and Preparation}

More than 3600 fragments were recovered [33], 145 of which were studied in detail, of which a final selection of 50 samples was made for color, elemental and molecular analyses (Table 1). The selection aimed to obtain a representative number of fragments from each cultural period. Therefore, we selected fragments that allowed for a detailed characterization and well-defined position within the deposit stratigraphy.

The surfaces of the pottery fragments were carefully and gently cleaned from externally bound sediment using distilled water, and the samples were ground to very fine powder $(<50 \mu \mathrm{m})$. 
Table 1. Sample codes, cultural period and possible sources of contamination (VAR1 and VAR2, see Section 3.3). Continuous variables correspond to elemental analysis $(\% \mathrm{C}$, molar $\mathrm{C} / \mathrm{N})$ and CIELAB color parameters for luminosity $\left(\mathrm{L}^{*}\right)$, redness $\left(\mathrm{a}^{*}\right)$, yellowness $\left(\mathrm{b}^{*}\right)$, chroma $(\mathrm{Chr})$ and hue.

\begin{tabular}{|c|c|c|c|c|c|c|c|c|c|c|}
\hline Sample & Cultural Period & VAR1 & VAR2 & $\% \mathrm{C}$ & $\mathrm{C}: \mathrm{N}$ & $L^{*}$ & $a^{*}$ & $\mathbf{b}^{*}$ & Chr & Hue \\
\hline CAM4A-001 & Late Bronze Age I & Intermediate & Post waste deposit & 0.76 & 12.7 & 53 & 14 & 26 & 30 & 61 \\
\hline CAM4A-002 & Late Bronze Age II & Low & Post waste deposit & 1.26 & 18.9 & 49 & 10 & 21 & 23 & 65 \\
\hline CAM4A-006 & Late Bronze Age II & Low & Marine influence & 0.86 & 17.6 & 55 & 8 & 19 & 21 & 69 \\
\hline CAM4A-007 & Late Bronze Age II & Low & Marine influence & 1.20 & 20.1 & 47 & 3 & 10 & 10 & 74 \\
\hline CAM4A-009 & Late Bronze Age I & Intermediate & Post waste deposit & 0.65 & 15.8 & 47 & 13 & 26 & 29 & 64 \\
\hline CAM4A-010 & Early Bronze Age & Intermediate & Post waste deposit & 1.36 & 13.6 & 48 & 6 & 14 & 15 & 69 \\
\hline CAM4A-011 & Middle Bronze Age & Intermediate & Post waste deposit & 1.28 & 12.6 & 50 & 9 & 22 & 24 & 67 \\
\hline CAM4A-012 & Late Bronze Age II & Low & Marine influence & 1.53 & 17.2 & 42 & 6 & 15 & 16 & 68 \\
\hline CAM4A-013 & Middle Bronze Age & High & Waste deposit & 3.29 & 33.3 & 39 & 10 & 19 & 22 & 63 \\
\hline CAM4A-014 & Late Neolithic & High & Waste deposit & 1.08 & 14.0 & 50 & 5 & 14 & 14 & 71 \\
\hline CAM4A-015 & Early Bronce Age & High & Waste deposit & 1.12 & 14.9 & 55 & 14 & 26 & 30 & 63 \\
\hline CAM4A-016 & Middle Bronze Age & High & Waste deposit & 0.87 & 14.2 & 53 & 18 & 31 & 36 & 61 \\
\hline CAM4A-018 & Late Neolithic & Intermediate & Post waste deposit & 2.27 & 34.5 & 34 & 2 & 11 & 11 & 77 \\
\hline CAM4A-021 & Early Bronze Age & Low & Post waste deposit & 2.49 & 25.9 & 33 & 2 & 6 & 7 & 69 \\
\hline CAM4A-025 & Late Bronze Age I & Intermediate & Post waste deposit & 2.07 & 18.8 & 36 & 6 & 14 & 15 & 68 \\
\hline CAM4A-034 & Late Bronze Age II & Low & Marine influence & 1.50 & 21.9 & 43 & 3 & 11 & 11 & 72 \\
\hline CAM4A-035 & Late Bronze Age I & Intermediate & Marine influence & 0.79 & 16.9 & 50 & 12 & 24 & 27 & 64 \\
\hline CAM4A-037 & Late Bronze Age I & Intermediate & Post waste deposit & 1.89 & 23.3 & 38 & 8 & 16 & 18 & 65 \\
\hline CAM4A-040 & Middle Bronze Age & High & Waste deposit & 3.12 & 27.6 & 33 & 5 & 11 & 12 & 66 \\
\hline CAM4A-045 & Middle Bronze Age & High & Waste deposit & 0.82 & 12.6 & 48 & 8 & 19 & 21 & 67 \\
\hline CAM4A-046 & Early Bronze Age & High & Waste deposit & 1.44 & 12.7 & 53 & 6 & 16 & 17 & 69 \\
\hline CAM4A-049 & Early Bronze Age & Low & Marine influence & 1.53 & 14.5 & 42 & 7 & 17 & 19 & 69 \\
\hline CAM4A-050 & Middle Bronze Age & Intermediate & Post waste deposit & 1.03 & 20.1 & 58 & 15 & 29 & 32 & 63 \\
\hline CAM4A-058 & Early Bronze Age & High & Waste deposit & 2.47 & 25.4 & 44 & 5 & 14 & 15 & 69 \\
\hline CAM4A-059 & Early Bronze Age & High & Waste deposit & 1.75 & 14.7 & 44 & 5 & 14 & 15 & 72 \\
\hline CAM4A-062 & Middle Bronze Age & High & Waste deposit & 1.19 & 14.9 & 49 & 10 & 21 & 23 & 66 \\
\hline CAM4A-063 & Early Bronze Age & High & Waste deposit & 1.39 & 13.5 & 54 & 9 & 20 & 21 & 65 \\
\hline CAM4A-065 & Middle Bronze Age & High & Waste deposit & 1.77 & 18.5 & 42 & 5 & 14 & 15 & 69 \\
\hline CAM4A-066 & Early Bronze Age & Intermediate & Post waste deposit & 0.98 & 13.7 & 45 & 4 & 14 & 15 & 73 \\
\hline CAM4A-069 & Early Bronze Age & Intermediate & Post waste deposit & 1.83 & 15.9 & 40 & 5 & 13 & 14 & 68 \\
\hline CAM4A-070 & Late Neolithic & High & Waste deposit & 2.05 & 16.4 & 37 & 3 & 9 & 10 & 70 \\
\hline CAM4A-071 & Middle Bronze Age & Low & Marine influence & 2.05 & 29.6 & 39 & 5 & 14 & 14 & 70 \\
\hline CAM4A-072 & Late Neolithic & High & Waste deposit & 2.00 & 20.4 & 39 & 4 & 10 & 11 & 70 \\
\hline CAM4A-073 & Middle Bronze Age & High & Waste deposit & 1.56 & 18.4 & 41 & 4 & 12 & 13 & 70 \\
\hline CAM4A-075 & Middle Bronze Age & Hight & Waste deposit & 0.92 & 16.6 & 50 & 17 & 30 & 34 & 60 \\
\hline CAM4A-077 & Middle Neolithic & Intermediate & Marine influence & 1.49 & 20.2 & 42 & 7 & 17 & 18 & 68 \\
\hline CAM4A-080 & Late Bronze Age II & High & Marine influence & 4.99 & 37.1 & 27 & 2 & 5 & 5 & 68 \\
\hline CAM4A-081 & Late Bronze Age II & High & Marine influence & 2.46 & 14.2 & 39 & 2 & 8 & 9 & 74 \\
\hline CAM4A-082 & Early Bronze Age & High & Waste deposit & 1.26 & 19.1 & 45 & 9 & 20 & 22 & 66 \\
\hline CAM4A-085 & Late Bronze Age I & Low & Marine influence & 4.56 & 52.9 & 27 & 3 & 6 & 7 & 63 \\
\hline CAM4A-091 & Late Neolithic & Intermediate & Post waste deposit & 0.95 & 12.4 & 48 & 9 & 18 & 20 & 64 \\
\hline CAM4A-092 & Late Neolithic & High & Waste deposit & 1.71 & 11.2 & 39 & 3 & 10 & 11 & 71 \\
\hline CAM4A-097 & Middle Bronze Age & High & Waste deposit & 1.37 & 23.0 & 52 & 6 & 17 & 18 & 69 \\
\hline CAM4A-100 & Late Neolithic & Low & Marine influence & 1.95 & 24.6 & 32 & 5 & 11 & 12 & 67 \\
\hline CAM4A-101 & Late Neolithic & Low & Marine influence & 1.04 & 15.6 & 57 & 2 & 9 & 9 & 75 \\
\hline CAM4A-102 & Early Bronze Age & High & Waste deposit & 1.23 & 17.6 & 47 & 8 & 18 & 20 & 66 \\
\hline CAM4A-103 & Middle Bronze Age & High & Waste deposit & 1.31 & 15.9 & 48 & 5 & 15 & 16 & 71 \\
\hline CAM4A-105 & Middle Bronze Age & High & Waste deposit & 2.31 & 30.1 & 33 & 4 & 9 & 9 & 66 \\
\hline CAM4A-107 & Late Bronze Age I & Intermediate & Post waste deposit & 1.47 & 19.9 & 49 & 12 & 24 & 27 & 63 \\
\hline CAM4A-109 & Middle Bronze Age & High & Waste deposit & 1.79 & 28.1 & 40 & 5 & 14 & 15 & 69 \\
\hline
\end{tabular}

\subsection{Color and Elemental Analyses}

Quantitative color analysis in the CIE $L^{*} a^{*} b^{*} C^{*} h(C I E L A B)$ color space was done using a Konica Minolta CR-5 colorimeter [34]. Samples were analyzed in the powder form. $\mathrm{L}^{*}$ represents luminosity $(\mathrm{L})$, primary color components ( $\mathrm{a}^{*}$ : green-red axis, and 
$b^{*}$ : blue-yellow axis) chromaticity $\left(C^{*}\right)$ and hue (h). Carbon and nitrogen contents were obtained by combustion of $100 \mathrm{mg}$ of finely milled samples using a Truspec CHNS analyzer (Leco) hosted at the RIAIDT services of the University of Santiago de Compostela.

\subsection{THM-GC-MS}

An aliquot of $10 \mu \mathrm{L}$ of tetramethylammonium hydroxide (TMAH, in water, $25 \%$, Sigma-Aldrich, St. Louis, MO, USA) was added to the fire-polished quartz tubes in which $1-2 \mathrm{mg}$ of sample was embedded. The setpoint temperature of the THM reaction was $650^{\circ} \mathrm{C}$, maintained for $20 \mathrm{~s}$, using a Pyroprobe pyrolyzer (CDS Analytical, Oxford, PA, USA). The pyrolyzer was connected online to an 8860 GC (Agilent, Santa Clara, USA). Analytical-grade helium was the carrier gas $(1 \mathrm{~mL} / \mathrm{min}$ constant flow). The pyrolyzer's interface oven, the GC inlet and the GC-MS interface were held isothermally at $325^{\circ} \mathrm{C}$. The GC was equipped with a HP-5MS non-polar column, and was in split mode (1:25). The GC was heated from 60 to $325{ }^{\circ} \mathrm{C}$ at a rate of $20^{\circ} \mathrm{C} / \mathrm{min}$. The initial and final isothermal periods were 5 and $2.5 \mathrm{~min}$, respectively (total runtime $19.75 \mathrm{~min}$ ). The MS operated in electron ionization $(70 \mathrm{eV})$ mode, scanning in the range of 50 to $500 \mathrm{amu}$, using a solvent delay period of $5 \mathrm{~min}$ to allow the residues of the TMAH and aqueous solvent to elute before the MS was activated. Relative abundances between the THM products (identified by literature and NIST libraries) were based on peak areas of their dominant $m / z$ fragments (Appendix A) and expressed as percentage of total quantified peak area (\% TQPA). For background on THM-GC-MS, readers may refer to Challinor [24], and for recent applications in diverse fields, to $\mathrm{He}$ et al. [35].

\subsection{Data Evaluation}

We applied principal component analysis (PCA) on the relative proportions data from THM-GC-MS, after applying a centred logratio transformation (clr) to avoid the close data nature of compositional data. We used one-way analysis of variance (ANOVA) to explore differences between samples of different periods and different depositional features (alleged influence of external factors such as marine influence). All statistical tests were performed in SPSS 20.0 software (IBM, New York, NY, USA).

\section{Results and Discussion}

\subsection{Color and Elemental Analysis}

The ceramic fragments analyzed generally had low luminosity $\left(\mathrm{L}^{*}, n=50 ; 44.1 \pm 7.6\right.$; Table 1$)$ and chromaticity was low as well $\left(C^{*}, 17.6 \pm 7.4\right)$. The color components $a^{*}$ and $\mathrm{b}^{*}$ had positive values, indicating that the basal color is a mixture of red and yellow, with predominance of yellow over red as the hue exceeds $45^{\circ}$ in all measured samples.

The elemental analysis showed that carbon (C) contents ranged from 0.65 to $4.99 \%$ $(1.68 \pm 0.87 \%$; Table 1$)$, while nitrogen $(\mathrm{N})$ content ranged from 0.05 to $0.21 \%(0.10 \pm 0.03 \%)$ The C/N molar ratio ranged from 11.2 to $52.9(19.9 \pm 7.8)$.

Figure 2 shows some relationships between luminosity and elemental composition (\%C and C/N). Clearly, dark-colored (i.e., low luminosity value) samples have higher $\mathrm{C}$ content and higher $\mathrm{C} / \mathrm{N}$ than light-colored ceramic fragments. Hence, $\mathrm{OM}$ is the main component that decreases luminosity. The negative correlation between $\mathrm{L}^{*}$ and $\mathrm{C} / \mathrm{N}$ indicates that the darkening agent is enriched in $\mathrm{C}$ relative to $\mathrm{N}$. 

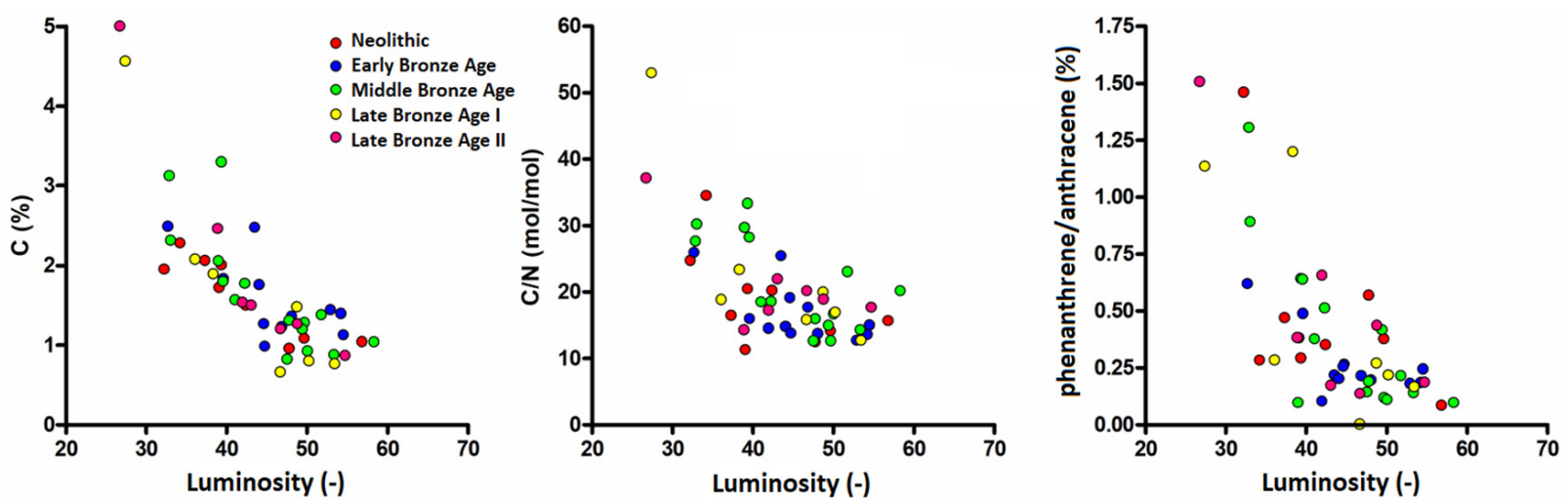

Figure 2. Relationship between luminosity $\left(\mathrm{L}^{*}\right)$ and carbon (left), $\mathrm{C} / \mathrm{N}$ molar ratio (center) and the relative proportion of co-eluting THM products phenanthrene and anthracene (right).

\subsection{Thermally Assisted Hydrolysis and Methylation (THM-GC-MS)}

The THM-GC-MS chromatograms (Figure 3; Supplementary Material) allowed to identify and semi-quantify 104 compounds (Appendix A). Most of the THM products have a molecular structure based on polymethylene chains ( $32.5 \pm 17.9 \%$ of TQPA; Figure 4$)$. The dominant subgroup of these compounds are fatty acid methyl esters (FAMEs), accompanied with fatty diacids (DAMEs), linear alkanes and isoprenoid alkanes. The carbon number of the FAMEs ranges between 7 and 18. These compounds can originate from oils and fats (food remains) but also from fatty acid moieties from plant remains and microbial sources (plankton, fungi, bacteria, etc.). The presence of branched (iso/anteiso) $\mathrm{C}_{15}$ FAME probably indicates that at least some of the FAMEs originate from bacterial sources of OM. We identified traces of only one FAME with mid-chain methoxy substitution, probably from cutin (plant cuticles) in selected samples. We searched for some of the markers reported by Shoda et al. [25] and identified a minor trace of a compound that was tentatively ascribed to an isoprenoid pristane-based FAME with $m / z 88$ and 312 at the expected retention time of pristanic acid methyl ester (ME), and possibly $m / z 101$ and 326 of phytanic acid ME (too small for peak area calculation). It is concluded that the abundance (relative to total OM that was accounted for in the THM-GC-MS data evaluation) in the studied sherds is much lower than that of the samples studied by these authors [25], or not present at all, and biomarker evaluation for palaeodiet in the present data is not sustained.

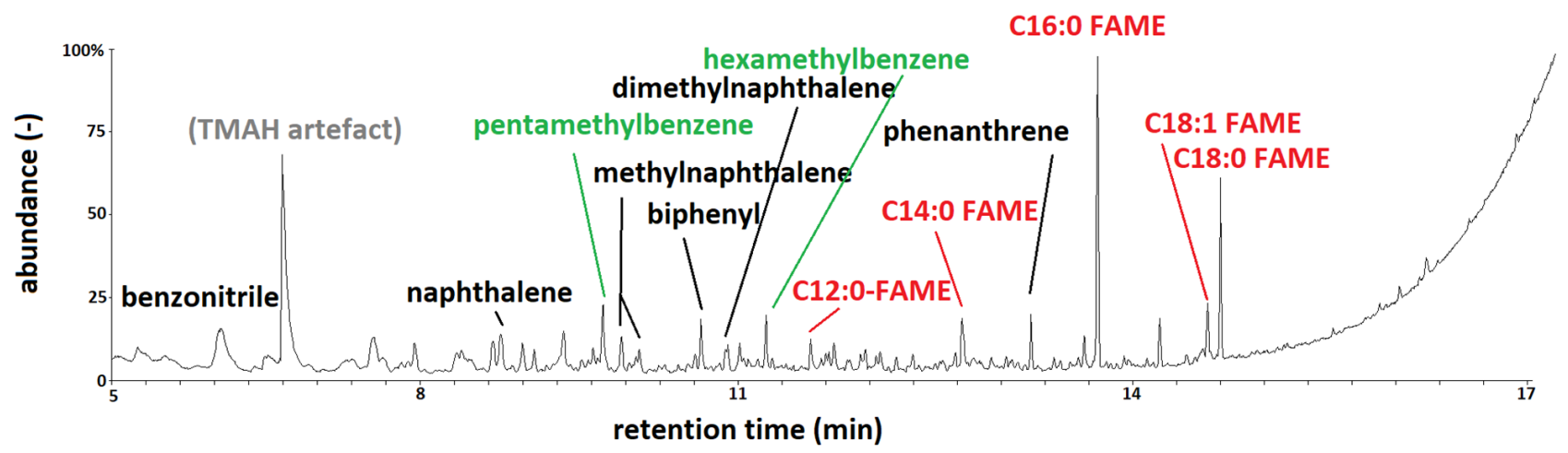

Figure 3. Example chromatogram (sample CAM4A-100) showing products of fatty acids (FAMEs, in red), polyalkylaromatic compounds (green) and polycyclic aromatic hydrocarbons (black). 

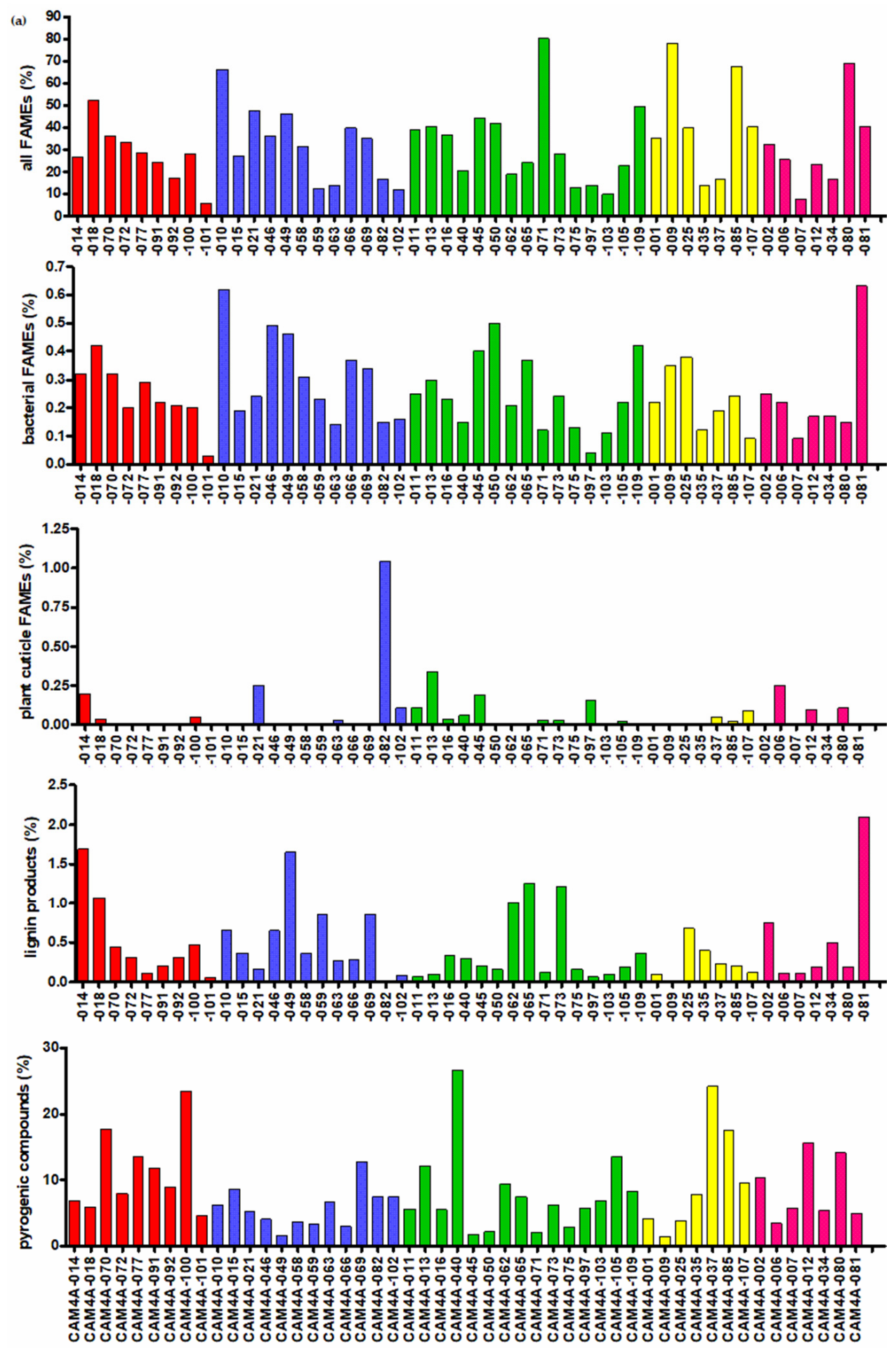

Figure 4. Cont. 

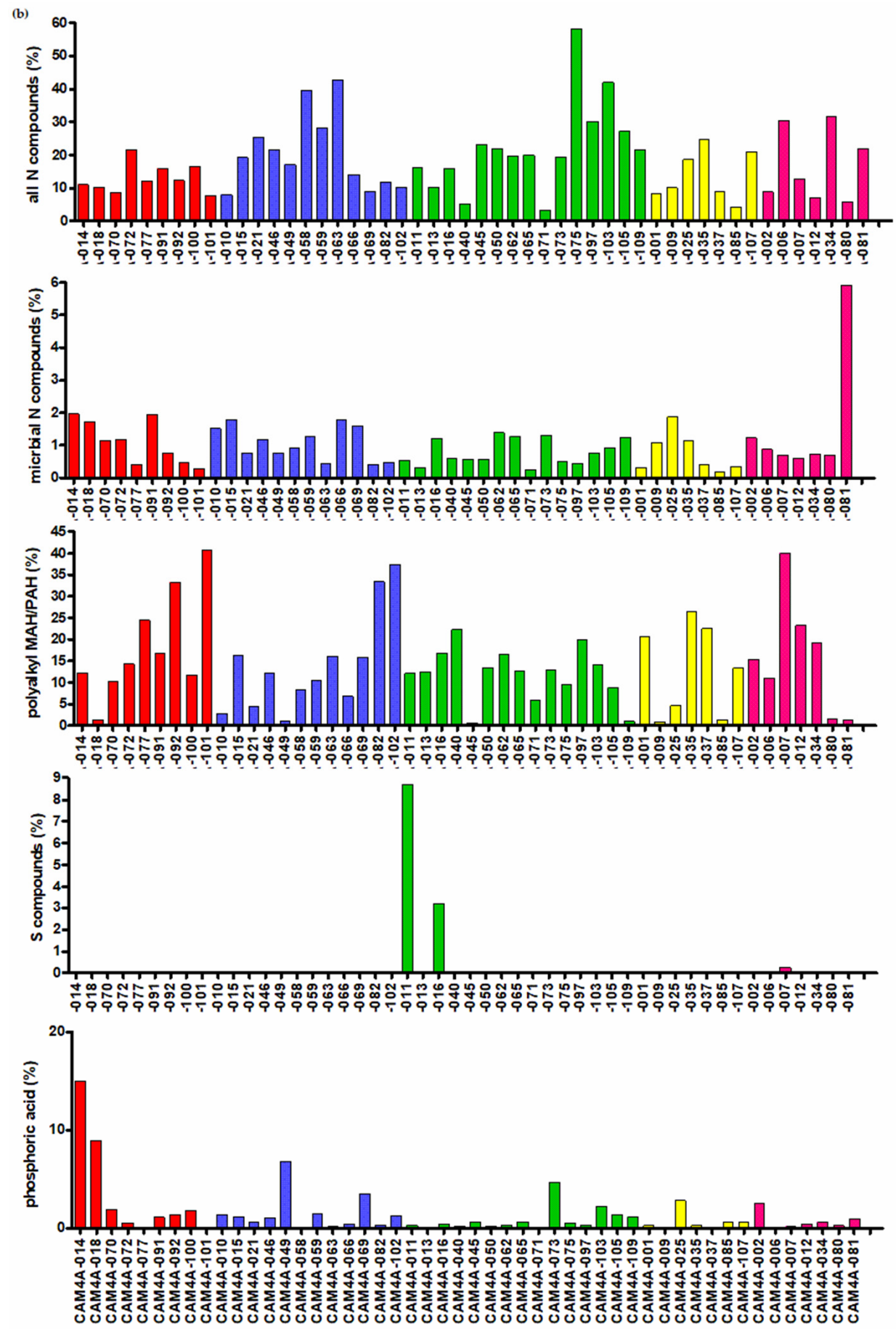

Figure 4. (a) Relative proportions of major groups of THM products: all FAMEs, bacterial-derived FAMEs; plant-derived FAMEs (cutin); lignin products and PyOM products. (b) Sum of N-compounds; microbial N-compounds (succinimide, uracil), poly-alkyl-aromatic MAHs and PAHs; S-compounds; methylated phosphoric acid. olors indicate cultural periods (red: Neolithic, blue: Early Bronze Age; green: Middle Bronze Age, yellow: Late Bronze Age I, magenta: Late Bronze Age II).

Many compounds with at least one atom of nitrogen ( $\mathrm{N}$-compounds) were identified $(18.2 \pm 11.2 \%$; Appendix A), further indicating the contribution of microbial OM to the molecular fingerprints. These compounds include alkylpyrroles, alkylindoles, anilines and succinic acid ME. In addition to microbial $\mathrm{N}$, these compounds (except for succinic acid $\mathrm{ME}$ ) can also originate from plant protein, but as discussed below, on the basis of statistical data evaluation, this is an unlikely source of N. Finally, the N-compound benzonitrile 
was also identified in the chromatograms of most samples. The most probable source of benzonitrile is pyrogenic OM (PyOM) [20].

This PyOM is also the likely source of polycyclic aromatic hydrocarbons (PAHs; $20.7 \pm 9.8 \%$ ), which are more abundant than is usual for THM fingerprints of biomass. In all likelihood, this can be explained by the substantial portion of charred remains in the OM in the sherds, formed during firing (incomplete burn-off) or cooking (soot, charred food). The first source of PyOM signals is usually dominant for ceramics produced (partially) at low temperature or with truncated firing (reflected by a dark-colored core in contrast to light-colored surfaces, also referred to as "sandwich" morphologies, with a heat-isolated dark-colored nucleus; $[8,36,37])$.

The compounds with a phenolic moiety include the ME of 4-methoxybenzoic acid (P6), 3,4-dimethoxybenzoic acid (G6) and 3,4,5-trimethoxybenzoic acid (S6). These compounds may originate from plant-derived polyphenols (most importantly, lignin and tannin), which may be detectable due to inclusion of soil OM (from the deposition environment), due to incomplete burn-off of organic temper, or from food remains (fiber). These compounds are scarce $(0.4 \pm 0.5 \%)$.

Monocyclic aromatic products include penta- and hexamethylbenzene $(14.5 \pm 11.4 \%)$, which may originate from marine sources [38] and which had not been observed in a study of fragments from non-coastal settlements in NW Spain [20]. This may indicate that some of $\mathrm{N}$-compounds also originate from marine sources such as plankton, as will be discussed later.

Finally, we identified several compounds containing sulfur (pronounced in two samples from the Middle Bronze Age) or phosphorus (most abundant in two samples from the Neolithic period; Figure 4), other compounds from contamination such as tert-butylphenol derivatives (plastic additive, surfactant), and compounds which may be formed during the THM reactions as secondary rearrangements such as branched alkanes. We are aware that the THM reaction may generate artifacts, which can be catalyzed by the presence of Fe oxides [39].

In summary, the THM-GC-MS analyses indicate the presence of OM that has a prefiring origin (temper-derived PyOM, perhaps some of the FAMEs), vessel use origin (soot-derived PyOM, perhaps some food-derived FAMEs) and from after burial (microbial OM from soil and marine fluxes, lignin and FAMEs).

The PCA (Figure 5) provided 3 PCs that explain $60 \%$ of total variance. PC1 has elevated negative loadings for the short-chain FAMEs including bacterial FAMEs and positive ones for polyalkyl aromatic compounds. PC1 is not correlated to other variables and is not of major interest for ceramic use identification, as it indicates the balance between different post-depositional inputs and, possibly, also analytical artifacts.

PC2 has high positive loadings for $\mathrm{N}$-containing and lignin products (G6, S6) and negative ones for $\mathrm{C}_{18}$ FAME. A possible explanation is that PC2 marks the input of postdepositional "exogenous" inputs (from the deposit), such as microbial and plant-derived soil OM constituents.

PC3 is easier to attribute to a specific source of OM, with high loadings for PyOM products (benzonitrile, fluorene, naphthalene, methylnaphthalenes, biphenyl, methylbiphenyl, phenanthrene/anthracene).

Regarding differences between samples, and based on the argued main likely sources of the THM products (Table 2), samples with the highest relative proportion of PyOM are CAM4A-037, $-040,-080,-085$ and -100 , corresponding to various periods. We believe that the most likely source of the PyOM is the incomplete combustion of soil OM from collected raw material and organic binder/temper, either way "pre-firing". If so, this means that these samples were subjected to a firing regime that facilitated preservation of OM, e.g., due to low temperature or short duration; or other parameters such as use of thick material and/or relatively high loads of temper. Dealing with relative proportions implies that it can also be simply that these fragments are relatively "clean" (few food or post-depositional organic inclusions). A source in surface-bound soot is unlikely due to associations between 
PC3 and color analysis (indicating bulk OM contributing to low $L^{*}$, not effects of a thin layer of surface-adhered soot).
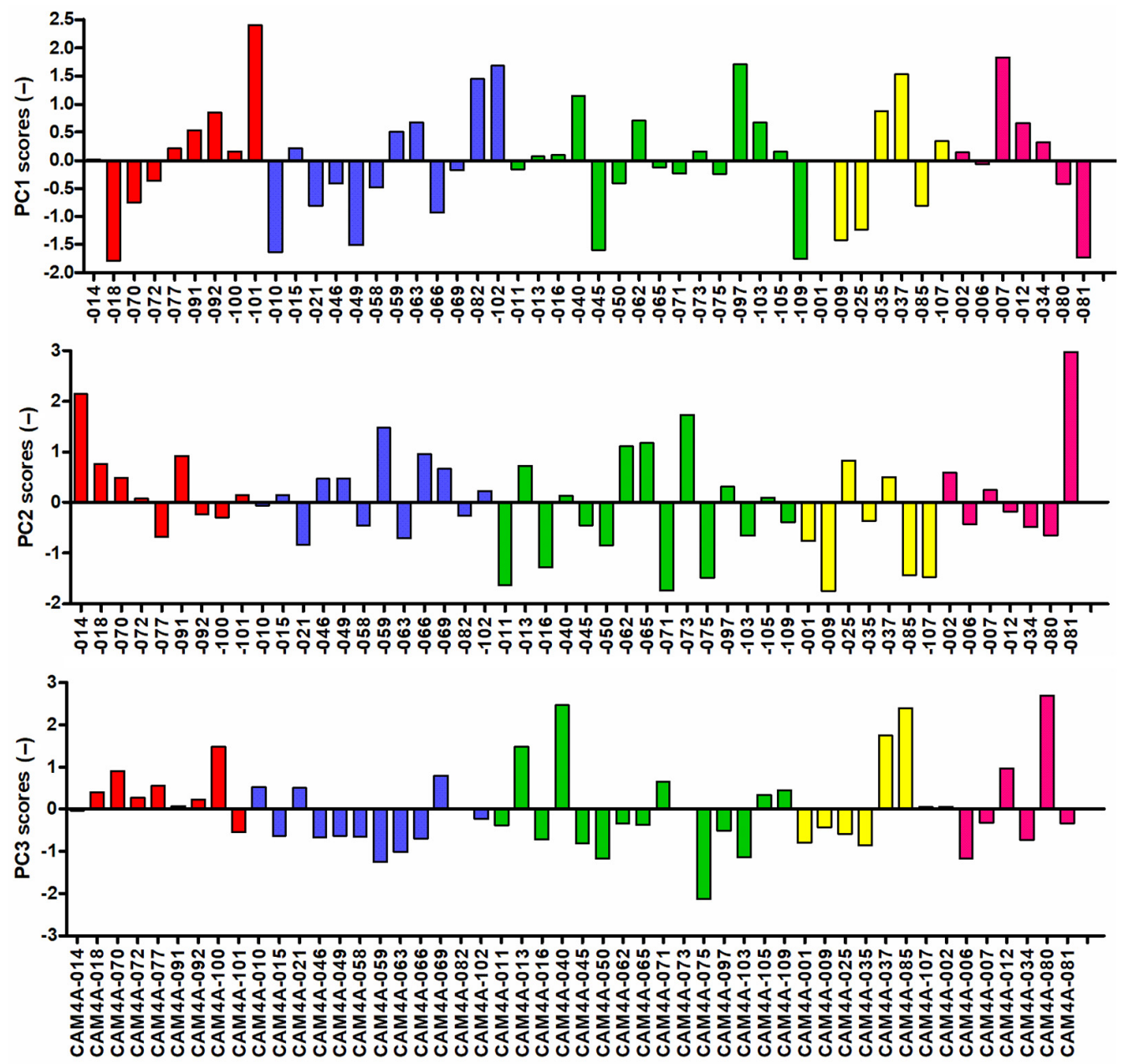

Figure 5. PC scores from THM-GC-MS after PCA. Colors indicate cultural periods (red: Neolithic, blue: Early Bronze Age; green: Middle Bronze Age, yellow: Late Bronze Age I, magenta: Late Bronze Age II).

Table 2. Main organic matter types identified, with their likely origin (unlikely alternatives within parentheses) and their loadings on PC1-PC3 from the principal component analysis.

\begin{tabular}{|c|c|c|c|c|c|}
\hline Group & Fatty Acids & РyOM & $\begin{array}{c}\text { Polyalkyl } \\
\text { Aromatic } \\
\text { Compounds }\end{array}$ & $\begin{array}{l}\text { Nitrogen } \\
\text { Compounds }\end{array}$ & Polyphenols \\
\hline Description & FAMEs & $\begin{array}{l}\text { Pyrogenic organic } \\
\text { matter products }\end{array}$ & $\begin{array}{c}\text { Polyalkyl } \\
\text { MAH/PAH }\end{array}$ & $\begin{array}{l}\text { Products with } \\
\text { nitrogen }\end{array}$ & Lignin (P6, G6, S6) \\
\hline Origen & microbial/dietary & $\begin{array}{c}\text { Interior ceramic } \\
\text { (temper/binder), } \\
\text { exterior (soot) }\end{array}$ & Tentatively marine & $\begin{array}{c}\text { Microbial } \\
\text { (marine/terrestrial), } \\
\text { molluscs }\end{array}$ & Plant remains \\
\hline Indicator & Food/abandonment & Firing/cooking & abandonment & abandonment & abandonment \\
\hline PCA & $-\mathrm{PC} 1$ & $+\mathrm{PC} 3$ & $+\mathrm{PC} 1$ & $+\mathrm{PC} 2$ & $+\mathrm{PC} 2$ \\
\hline $\begin{array}{l}\text { Operative } \\
\text { chain? }\end{array}$ & $\begin{array}{c}\text { Post- } \\
\text { depositional/dietary }\end{array}$ & $\begin{array}{l}\text { Temper and soil OM } \\
\text { in raw material }\end{array}$ & Post-depositional & $\begin{array}{c}\text { Post-depositional } \\
\text { (proteinaceous food) }\end{array}$ & $\begin{array}{l}\text { Post-depositional } \\
\text { (temper) }\end{array}$ \\
\hline
\end{tabular}

Part of the variation can indicate the balance between fatty acids and compounds of microbial origin (FAMEs, poly-alkyl MAH and PAH, PC1). If part of the non-microbial FAMEs detected indeed originate from food remains, this would imply a great value for 
selecting samples for future analysis. In this regard, samples CAM4A-018 and -081 have signals that may be the most likely associated with food remains. Samples CAM4A-007, $-082,-097,-101$ and -102 would have relatively strong marine influence. For fragment CAM4A-101 this coincides with a sherd that is colonized by mollusks.

Samples with the highest proportions of lignin and microbial N are CAM4A-014 and 081. The most likely explanation is a relative strong signal from terrestrial post-depositional inclusions (fungi and plant remains). But an effect of decay intensity cannot be discarded as chitin and lignin are probably among the labile sources of $\mathrm{OM}$ in the present environment. Bacterial FAMEs are most abundant in CAM4A-010 and -081, and least abundant in -097 and -101. Finally, sample CAM4A-082 has a relatively strong signal of leaf cuticle-derived OM (cutin).

\subsection{Comparing THM Data with Color and Elemental Composition}

The strongest correlation between the different datasets is the negative link between luminosity $\left(\mathrm{L}^{*}\right)$ and the PyOM-related PAHs such as naphthalene, fluorene, biphenyls and phenanthrene/anthracene (Figure 2), benzonitrile and PC3. This link between darkness and PyOM is a strong indication of incomplete burn-off as the cause. It was also the main link between color and Py-GC-MS analyses of pottery fragments from non-coastal settlements in NW Spain [20]. It is remarkable that the THM-GC-MS data also highlight such an effect as the main products of PyOM, benzene and toluene, are not detected by THM-GC-MS. The total sum of PAH is not correlated to L* probably because of contributions from non-PyOM, such as plankton, to the poly-alkyl PAHs (mainly polyalkylnaphthalenes and -indenes). Indeed, trimethylindene and hexamethylbenzenes are correlated positively with $\mathrm{L}^{*}$. There is no apparent effect of cultural period on $\mathrm{L}^{*}$ or molecular proxies of PyOM (low values for $L^{*}$ and high values for PyOM for samples CAM4A-009, -037, -040, -080, -085 and -105). These data reflect low firing temperature and/or ceramic thickness (preservation of binder/temper in inner sections), but we have not elaborated this further as Py-GCMS is more suitable for these purposes and because of the likely catalytic effects of Fe oxides $[18,40]$.

The negative correlations between $\mathrm{L}^{*}, \% \mathrm{C}, \mathrm{C} / \mathrm{N}$ and PyOM indicates that the PyOM has an effect on $\mathrm{L}^{*}$ that the $\mathrm{OM}$ from $\mathrm{N}$-rich marine and terrestrial microbial sources does not have. The relationships between other color parameters and the molecular fingerprints are relatively weak and may be due to spurious co-variation effects. Suffice it to mention that the PyOM tends to mitigate the expression of $\mathrm{a}^{*}$ (redness) component, probably related to Fe oxides, to a larger extent than $b^{*}, C^{*}$ or $h$. This negative effect of PyOM on redness may also be related to the association of PyOM with low temperatures (caused by incomplete burn-off) that would also reduce the efficiency of Fe (oxy)hydroxide dehydration to strongly pigmenting red oxides such as hematite. Note that this negative effect makes it unlikely that Fe oxide-catalyzed secondary reactions are the main formation mechanism of PyOM products, lending support to our approach and interpretation of PC 3 . The $\% \mathrm{C}$ is negatively correlated with polyalkyl MAH and PAH, probably due to the fact that the THM-GC-MS data is a closed dataset: molecular fingerprints of samples with low OM content will be more strongly affected by marine-derived OM than samples with high OM content. Indeed, we did not find consistent trends between the intensity of the marine signal from THM and position in the deposits or age/cultural period. If this argument is correct, the variations in the fingerprints indicate that not only the PyOM but also the mentioned FAMEs are mainly pre-depositional. Then, the marine, and probably also terrestrial signals (microbial N-rich moieties and plant-derived lignin and perhaps cutin) developed mainly post-depositionally.

The correlations between $\% \mathrm{~N}$ and THM products are different to those for $\%$ C. For $\% \mathrm{~N}$, positive correlations $(p<0.001)$ were observed for $i s o-\mathrm{C}_{15}$ FAME (bacterial lipids), $\mathrm{C}_{9}$-diacid (degraded $\mathrm{C}_{18}$ fatty acids), $\mathrm{N}$ compounds (alkylindoles, $\mathrm{N}$-methylsuccinimide) and the phenolic products P6 y G6. This highlights the influence of soil microbes (bacteria and fungi) on OM composition. The association between microbial and lignin products 
further supports a post-depositional source of lignin, instead of incomplete burn-off of organic temper or soil OM that was present in the raw material before firing. Perhaps the inclusion of plant signals is stimulated by microbial activity on sherd surfaces, or because enhanced microbial alteration provokes stronger interactions between the ceramic fabric and the soil environment in general. Relationships between THM fingerprint and $\mathrm{C} / \mathrm{N}$ are consistent, with correlations between $\mathrm{C} / \mathrm{N}$ with FAMEs and PyOM markers.

The ANOVA analysis using cultural period (Neolithic, Early Bronze Age, Middle Bronze Age, Late Bronze Age I and Late Bronze Age II; 7-15 samples/period) revealed few significant differences in molecular composition of the OM. The tentatively identified isoprenoid FAME (pristanic acid ME) is enriched in samples from Late Bronze Age I, which could reflect an effect of different vessel use between periods (marine oils), but in the light of planktonic aquatic sources of OM and the uncertainty in identification of this compound, this observation cannot be considered more than a reason to pursue further analyses using alternative methods of the samples from the Late Bronze Age I in particular. Furthermore, an aliphatic ether is enriched in samples from the Early Bronze Age, and phosphoric acid ME in samples from the Neolithic. Color data are more strongly differentiated on the basis of period, with low values of $\mathrm{a}^{*}, \mathrm{~b}^{*}$ and $\mathrm{C}^{*}$ in samples from the Late Bronze Age II and Neolithic, and high values for the other samples, in particular Middle Bronze Age and Late Bronze Age I. For hue, the tendency is reverse. This probably indicates differences in raw material selection and firing conditions, but because these results are not related to OM chemistry, they were not explored further.

An additional ANOVA aimed to identify differences between recovery locations. The midden was expected to coincide with samples with higher likelihood of post-depositional contamination (VAR1; high—intermediate-low) and contamination type (VAR2; waste deposit-post waste deposit-marine influence) than samples from the superimposed layers (Table 1). It appeared that samples with high general contamination likeliness (VAR1) were enriched in N-containing THM products (alkylindoles and-pyrroles), confirming a stronger microbial influence in the midden (including possibly mollusk-derived OM), whereas $\mathrm{C}_{16}$ FAME is enriched in samples with low contamination. There is no color effect on VAR1. For VAR2 (contamination type), samples from the waste deposit have positive PC1 scores from THM (low fatty acid proportions and high microbial influence) whereas the other two categories have negative PC1. Indeed, $\mathrm{C}_{16}$ and $\mathrm{C}_{18}$ FAME are depleted in the samples from the waste deposit. These results might indicate that samples that are prolific in FAMEs are good candidates for dietary analyses of the fatty acid profiles using compound-specific IRMS of lipid extracts.

\section{Conclusions}

The THM-GC-MS analyses have shown that the OM present in the ceramic fragments from Guidoiro Areoso Islet originated mainly from: (1) marine and terrestrial microorganisms (protein, chitin, bacterial fatty acids), (2) charred residues (PyOM, formed during firing, from soil OM or temper/binder), (3) uncharred plant remains (traces of lignin and cutin from post-depositional inclusion of plant-derived soil OM) and (4) fatty acids of unknown source (possibly from food remains). It is clear that the burial environment, with high loads of organic waste and marine influence, caused a relatively complex mixture of OM sources that hampered the unambiguous identification of food remains, let alone identifying precise ingredients. Nevertheless, the study revealed some interesting links between color, elemental and molecular composition of ancient ceramic fragments that allowed for a better understanding of the changes in deposition conditions and will be used to select a subset of samples of which relatively "clean" fatty acid patterns are expected, in particular dark-colored ones, with high $\mathrm{C} / \mathrm{N}$ and with high non-bacterial FAME proportions. We believe that light-colored fragments, with low fatty acid contents and low $\mathrm{C} / \mathrm{N}$, would reveal fatty acid profiles that are too severely affected by microbial inputs.

Supplementary Materials: The THM-GC-MS data are available online at https:/ / www.mdpi.com/ article/10.3390/separations8090140/s1. 
Author Contributions: Conceptualization, J.K., M.P.P.M. and A.M.C.; methodology, J.K., M.G.C.G. and A.M.C.; formal analysis, J.K. and A.M.C.; investigation, all authors; writing-original draft preparation, J.K.; writing - review and editing, all authors; visualization, J.K.; project administration, M.P.P.M. and A.M.C.; funding acquisition, M.P.P.M. and A.M.C. All authors have read and agreed to the published version of the manuscript.

Funding: This research was funded by Fundación Palarq under Project "Proyecto de análisis físicoquímicos de muestras orgánicas en la cerámica de la M4 de Guidoiro Areoso" (2019-2020).

Data Availability Statement: We will provide the background data as Supplementary Material.

Acknowledgments: We thank the Fundación Palarq for their generous support. We are grateful to Shinya Shoda (University of York, UK) for sharing THM-GC-MS chromatograms of Neolithic pottery, which helped to discard the biomarker potential of our obtained data. We acknowledge the valuable comments from two anonymous reviewers.

Conflicts of Interest: The authors declare no conflict of interest.

\section{Appendix A}

List of identified THM products, with the retention time (RT; in minutes), identification ( $\mathrm{T}=$ tentative), mass / charge ratio of ions used for peak area calculation $(\mathrm{m} / \mathrm{z})$ and group allocation. $\mathrm{ME}=$ methyl ester; FAME $=$ fatty acid methyl ester; DAME = fatty diacid; $\mathrm{PyOM}=$ pyrogenic origin; $\mathrm{MAH}=$ monocyclic aromatic hydrocarbon; $\mathrm{PAH}=$ polycyclic aromatic hydrocarbon; $\mathrm{BCA}=$ benzenecarboxylic acid methyl ester; $\mathrm{NCOMP}=$ nitrogen compound; $\mathrm{SCOMP}=$ sulfur compound; $\mathrm{MCC}=$ polymethylene compounds other than FAMEs and DAMEs).

\begin{tabular}{|c|c|c|c|}
\hline RT (min) & Compound & $m / z$ & Group \\
\hline 6.270 & $\mathrm{C}_{7}$ FAME & 74 & FAME \\
\hline 7.406 & $\mathrm{C}_{8}$ FAME & 74 & FAME \\
\hline 8.340 & $\mathrm{C}_{9}$ FAME & 74 & FAME \\
\hline 9.149 & $\mathrm{C}_{10}$ FAME & 74 & FAME \\
\hline 9.865 & $\mathrm{C}_{11}$ FAME & 74 & FAME \\
\hline 10.519 & $\mathrm{C}_{12}$ FAME & 74 & FAME \\
\hline 11.132 & $\mathrm{C}_{13}$ FAME & 74 & FAME \\
\hline 11.702 & $\mathrm{C}_{14} \mathrm{FAME}$ & 74 & FAME \\
\hline 12.050 & iso- $\mathrm{C}_{15}$ FAME & 74 & FAME \\
\hline 12.097 & anteiso- $_{15}$ FAME & 74 & FAME \\
\hline 12.247 & $\mathrm{C}_{15}$ FAME & 74 & FAME \\
\hline 12.771 & $\mathrm{C}_{16}$ FAME & 74 & FAME \\
\hline 13.259 & $\mathrm{C}_{17}$ FAME & 74 & FAME \\
\hline 13.731 & $\mathrm{C}_{18}$ FAME & 74 & FAME \\
\hline 14.224 & $\mathrm{C}_{19}$ FAME & 74 & FAME \\
\hline 14.618 & $\mathrm{C}_{20}$ FAME & 74 & FAME \\
\hline 15.428 & $\mathrm{C}_{22}$ FAME & 74 & FAME \\
\hline 12.662 & $\mathrm{C}_{16: 1}$ FAME & 55 & FAME \\
\hline 13.632 & $\mathrm{C}_{18.1}$ FAME & 55 & FAME \\
\hline 12.662 & $\mathrm{C}_{18: 2}^{10.1}$ FAME & 67 & FAME \\
\hline 13.632 & $\mathrm{C}_{18.2}$ FAME & 67 & FAME \\
\hline 8.932 & unidentified alkane & 57 & MCC \\
\hline 9.679 & unidentified alkane & 57 & MCC \\
\hline 10.343 & unidentified alkane & 57 & MCC \\
\hline 10.675 & unidentified alkane (non homologous) & 57 & MCC \\
\hline 10.960 & unidentified alkane & 57 & MCC \\
\hline 11.334 & unidentified alkane & 57 & MCC \\
\hline 11.796 & unidentified alkane & 57 & MCC \\
\hline 14.359 & N,N-dimethylalkylamide & 87 & NCOMP \\
\hline 12.553 & unidentified MCC (alkene/ether) & 83 & MCC \\
\hline 13.311 & unidentified MCC (alkene/ether) & 83 & MCC \\
\hline 6.477 & $\mathrm{C}_{4}$ DAME & 59 & DAME \\
\hline 8.548 & $\mathrm{C}_{6} \mathrm{DAME}$ & 59 & DAME \\
\hline 10.696 & C DAME & 59 & DAME \\
\hline 5.912 & benzonitrile & 103 & PyOM \\
\hline 6.114 & phosphoric acid triME & 110 & OTHER \\
\hline 6.566 & indene & 116 & PyOM \\
\hline
\end{tabular}




\begin{tabular}{|c|c|c|c|}
\hline RT (min) & Compound & $m / z$ & Group \\
\hline 6.877 & $N$-methylaniline & 106 & NCOMP \\
\hline 6.893 & guaiacol $(\mathrm{T})$ & 109 & OTHER \\
\hline 7.141 & $N, N$-dimethylaniline & 120 & NCOMP \\
\hline 7.126 & benzenecarboxylic acid ME & 105 & BCA \\
\hline 7.271 & $N$-methylsuccinimide & 113 & NCOMP \\
\hline 7.448 & $C_{3}$-alkylbenzene & 119 & MAH \\
\hline 7.494 & tetramethylpyrrole & 123 & NCOMP \\
\hline 7.515 & unidentified compound (possibly N) & 139 & OTHER \\
\hline 7.806 & methylindene (DP) & 130 & PyOM \\
\hline 7.889 & $N, N, \mathrm{x}, \mathrm{x}$-tetramethylaniline & 149 & NCOMP \\
\hline 8.055 & $N, N, x$-trimethylaniline & 134 & NCOMP \\
\hline 8.106 & methylthioanisole $(\mathrm{T})$ & 138 & SCOMP \\
\hline 8.133 & naphthalene & 128 & PyOM \\
\hline 8.299 & pentamethylpyrrole & 136 & NCOMP \\
\hline 8.407 & $N, N$-dimethyluracil (T) (pyrimidinedione) & 140 & NCOMP \\
\hline 8.491 & unidentified compound & 121 & OTHER \\
\hline 8.537 & $\mathrm{C}_{5}$-alkylbenzene & 133 & MAH \\
\hline 8.864 & $\mathrm{C}_{2}$-alkylindene & 129 & PyOM \\
\hline 8.932 & $\mathrm{C}_{5}$-alkylbenzene & 133 & MAH \\
\hline 9.082 & methylnaphthalene & 142 & PyOM \\
\hline 9.144 & trimethylindene & 143 & PyOM \\
\hline 9.217 & methylnaphthalene & 142 & PyOM \\
\hline 9.341 & 4-methoxybenzoic acid ME (P6) & 135 & Phenolic \\
\hline 9.352 & $\mathrm{C}_{4}$-alkylpyrrolecarboxaldehyde $(\mathrm{T})$ & 136 & NCOMP \\
\hline 9.435 & $\mathrm{C}_{4}$-alkylpyrrolecarboxaldehyde (T) & 136 & NCOMP \\
\hline 9.450 & proline derivative & 98 & NCOMP \\
\hline 9.507 & aromatic compound $\left(\mathrm{C}_{10} \mathrm{H}_{14} \mathrm{O}\right)$ & 150 & OTHER \\
\hline 9.512 & $\mathrm{C}_{6}$-alkylbenzene & 147 & MAH \\
\hline 9.617 & $\mathrm{C}_{2}$-alkylindole & 144 & NCOMP \\
\hline 9.663 & trimethylindene & 143 & PyOM \\
\hline 9.715 & biphenyl & 154 & PyOM \\
\hline 9.788 & unidentified compound & 125 & OTHER \\
\hline 9.879 & $\mathrm{C}_{2}$-alkylnaphthalene & 141 & PyOM \\
\hline 10.006 & $\mathrm{C}_{2}$-alkylnaphthalene & 141 & PyOM \\
\hline 10.078 & diphenylmethane/methylbiphenyl & 167 & PyOM \\
\hline 10.011 & 2,6-diisopropylaniline & 162 & NCOMP \\
\hline 10.099 & 4-tert-butylbenzoic acid ME & 177 & OTHER \\
\hline 10.166 & benzenedicarboxylic di ME & 163 & BCA \\
\hline 10.213 & hexamethylbenzene & 147 & MAH \\
\hline 10.483 & benzenedicarboxylic di ME & 163 & $\mathrm{BCA}$ \\
\hline 10.563 & benzenedicarboxylic di ME & 163 & $\mathrm{BCA}$ \\
\hline 10.623 & $\mathrm{C}_{3}$-alkylnaphthalene & 155 & PyOM \\
\hline 10.649 & dihydro- $C_{3}$-alkylnaphthalene & 157 & PyOM \\
\hline 10.701 & tert-butylanisole & 149 & OTHER \\
\hline 10.711 & $\mathrm{C}_{3}$-alkylindole & 159 & NCOMP \\
\hline 10.960 & $\mathrm{C}_{3}$-alkylnaphthalene & 155 & PyOM \\
\hline 11.080 & $\mathrm{C}_{3}$-alkylnaphthalene & 155 & PyOM \\
\hline 11.002 & 3,4-dimethoxybenzoic acid ME (G6) & 196 & Phenolic \\
\hline 11.116 & fluorene & 166 & PyOM \\
\hline 11.360 & $\mathrm{C}_{4}$-alkylindole & 173 & NCOMP \\
\hline 11.500 & benzenesulfonamide (x,N-dimethyl) & 91 & SCOMP \\
\hline 11.795 & benzenesulfonamide (x,N-dimethyl) & 91 & SCOMP \\
\hline 11.697 & $\mathrm{C}_{4}$-alkylnaphthalene & 169 & PyOM \\
\hline 11.765 & unidentified compound & 193 & OTHER \\
\hline 11.759 & 3,4,5-trimethoxybenzoic acid ME (S6) & 226 & Phenolic \\
\hline 11.983 & $\mathrm{C}_{4}$-alkylnaphthalene & 169 & PyOM \\
\hline 12.284 & phenanthrene/anthracene & 178 & PyOM \\
\hline 12.475 & $\mathrm{C}_{5}$-alkylnaphthalene & 183 & PyOM \\
\hline 12.547 & $\mathrm{C}_{5}$-alkylnaphthalene & 183 & PyOM \\
\hline 13.025 & methylphenanthrene & 192 & PyOM \\
\hline 13.150 & unidentified isoprenoid hydrocarbon & 82 & MCC \\
\hline 13.466 & unidentified isoprenoid hydrocarbon & 82 & MCC \\
\hline 13.518 & unidentified compound & 212 & OTHER \\
\hline 13.850 & unidentified compound & 226 & OTHER \\
\hline 14.748 & mid-chain methoxy-FAME (cutin-like) & 201 & OTHER \\
\hline 14.914 & unidentified compound & 254 & OTHER \\
\hline 12.953 & pristane-based isoprenoid FAME $(\mathrm{T})$ & 88 & FAME \\
\hline
\end{tabular}




\section{References}

1. Heron, C.; Evershed, R.P. The analysis of organic residues and the study of pottery use. J. Archaeol. Method Theory 1993, 5, 247-284.

2. Evershed, R.P. Organic residue analysis in archaeology: The archaeological biomarker revolution. Archaeometry 2008, 50, 895-924. [CrossRef]

3. Malainey, M.E. Food-Related Pottery Residues. In A Consumer's Guide to Archaeological Science; Springer: New York, NY, USA, 2010; pp. 319-331. [CrossRef]

4. Roffet-Salque, M.; Dunne, J.; Altoft, D.T.; Casanova, E.; Cramp, L.J.E.; Smyth, J.; Whelton, H.L.; Evershed, R.P. From the inside out: Upscaling organic residue analyses of archaeological ceramics. J. Archaeol. Sci. Rep. 2017, 16, 627-640. [CrossRef]

5. $\quad$ Evershed, R.P.; Payne, S.; Sherratt, A.G.; Copley, M.S.; Coolidge, J.; Urem-Kotsu, D.; Kotsakis, K.; Özdoğan, M.; Özdoğan, A.E.; Nieuwenhuyse, O.; et al. Earliest date for milk use in the Near East and southeastern Europe linked to cattle herding. Nature 2008, 455, 528-531. [CrossRef]

6. Cubas, M.; Lucquin, A.; Robson, H.K.; Colonese, A.C.; Arias, P.; Aubry, B.; Billard, C.; Jan, D.; Diniz, M.; Fernandes, R.; et al. Latitudinal gradient in dairy production with the introduction of farming in Atlantic Europe. Nat. Commun. 2020, 11, 2036. [CrossRef]

7. Johnson, J.S.; Clark, J.; Miller-Antonio, S.; Schiffer, M.B.; Skibo, J.M. Effects of firing temperature on the fate of naturally occurring organic matter in clays. J. Archaeol. Sci. 1988, 15, 403-414. [CrossRef]

8. Skibo, J.M.; Schiffer, M.B.; Reid, K.C. Organic-tempered pottery: An experimental study. Am. Antiq. 1989, 54, 122-146. [CrossRef]

9. Stern, B.; Heron, C.; Serpico, M.; Bourriau, J. A comparison of methods for establishing fatty acid concentration gradients across potsherds. Archaeometry 2000, 42, 399-414. [CrossRef]

10. Oudemans, T.F.M.; Boon, J.J. Molecular archaeology: Analysis of charred (food) remains from prehistoric pottery by pyrolysis-gas chromatography/mass spectrometry. J. Anal. Appl. Pyrolysis 1991, 20, 197-227. [CrossRef]

11. Colombini, M.P.; Modugno, F. Organic Mass Spectrometry in Art and Archaeology; John Wiley \& Sons. Ltd.: Chichester, UK, 2009.

12. Shedrinsky, A.; Wampler, T.; Indictor, N.; Baer, N.S. Application of analytical pyrolysis to problems in art and archaeology: A review. J. Anal. Appl. Pyrolysis 1989, 15, 393-412. [CrossRef]

13. Chiavari, G.; Prati, S. Analytical pyrolysis as diagnostic tool in the investigation of works of art. Chromatographia 2003, 58, 543-554.

14. Tamburini, D.; Łucejko, J.J.; Zborowska, M.; Modugno, F.; Pradzynski, W.; Colombini, M.P. Archaeological wood degradation at the site of Biskupin (Poland): Wet chemical analysis and evaluation of specific Py-GC/MS profiles. J. Anal. Appl. Pyrolysis 2015, 115, 7-15. [CrossRef]

15. Kaal, J.; López Costas, O.; Martínez Cortizas, A. Diagenetic effects on pyrolysis fingerprints of extracted collagen in archaeological human bones from NW Spain, as determined by pyrolysis-GC-MS. J. Archaeol. Sci. 2016, 65, 1-10. [CrossRef]

16. Kaal, J.; Martín Seijo, M.; Oliveira, C.; Wagner-Wysiecka, E.; McCoy, V.; Kraemer, M.S.; Kerner, A.; Wenig, P.; Mayo, C.; Mayo, J.S. Golden artefacts, resin figurines, body adhesives and tomb sediments from the pre-Columbian burial site El Caño (Gran Coclé, Panamá): Tracing organic contents using molecular archaeometry. J. Archaeol. Sci. 2020, 113, 105045. [CrossRef]

17. Armada, X.-L.; García-Vuelta, O.; Kaal, J.; Martín-Seijo, M.; Porto, Y. Characterization of cores and organic remains in Iron Age gold objects: The Recouso treasure. Mater. Manuf. Process. 2017, 32, 740-748. [CrossRef]

18. Sáiz-Jiménez, C. Analytical pyrolysis of humic substances: Pitfalls, limitations, and possible solutions. Environ. Sci. Technol. 1994, 28, 1773-1780. [CrossRef]

19. Mills, J.; White, R. Organic Chemistry of Museum Objects, 2nd ed.; Routledge: London, UK, 2015; p. 222.

20. Kaal, J.; Lantes Suárez, O.; Martínez Cortizas, A.; Prieto Martínez, M.P. How useful is pyrolysis-GC/MS for the assessment of molecular properties of organic matter in archaeological pottery matrix? An exploratory case study from North-West Spain. Archaeometry 2014, 56, 187-207. [CrossRef]

21. Kaal, J.; Gilmore, Z. Itla-okla (Tillandsia usneoides) Fibre Temper in Pre-Columbian Ceramics. Analytical Pyrolysis Letters APL002. 2018. Available online: https:/ / pyrolyscience.com/apl002/ (accessed on 16 August 2021).

22. Sanjurjo Sánchez, J.; Kaal, J.; Montero Fenollós, J.L. Organic matter from bevelled rim bowls of the Middle Euphrates: Results from molecular characterization using pyrolysis-GC-MS. Microchem. J. 2018, 141, 1-6. [CrossRef]

23. Braadbaart, F.; Reidsma, F.H.; Roebroeks, W.; Chiotti, L.; Slon, V.; Meyer, M.; Théry-Parisot, I.; van Hoesel, A.; Nierop, K.G.J.; Kaal, J.; et al. Heating histories and taphonomy of ancient fireplaces: A multi-proxy case study from the Upper Palaeolithic sequence of Abri Pataud (Les Eyzies-de-Tayac, France). J. Archaeol. Sci. Rep. 2020, 33, 102468. [CrossRef]

24. Challinor, J.M. A pyrolysis-derivatisation-gas chromatography technique for the structural elucidation of some synthetic polymers. J. Anal. Appl. Pyrolysis 1989, 16, 323-333. [CrossRef]

25. Shoda, S.; Matsui, K.; Craig, O.E.; Watanabe, C.; Teramae, N. Rapid, cost-effective lipid analysis of small samples of archaeological ceramic by pyrolysis GC-MS. In Proceedings of the 8th International Symposium on Biomolecular Archaeology, Jena, Germany, 18-21 September 2018.

26. Hansel, F.A.; Copley, M.S.; Madureira, L.A.S.; Evershed, R.P. Thermally produced $\omega$-(o-alkylphenyl)alkanoic acids provide evidence for the processing of marine products in archaeological pottery vessels. Tetrahedron Lett. 2004, 45, 2999-3002. [CrossRef]

27. Bondetti, M.; Scott, E.; Courel, B.; Lucquin, A.; Shoda, S.; Lundy, J.; Labra-Odde, C.; Drieu, L.; Craig, O.E. Investigating the formation and diagnostic value of $\omega$-(o-alkylphenyl)alkanoic acids in ancient pottery. Archaeometry 2020, 63, 594-608. [CrossRef] 
28. Mañana Borrazás, P.; Blanco-Chao, R.; Bóveda Fernández, M.J.; Cajade-Pascual, D.; Costa-Casais, M.; Güimil Fariña, A.; López Romero, E.; Vázquez Collazo, S.; Vilaseco Vázquez, I. Lo que nos cuenta la marea. Prehistoria en el islote de Guidoiro Areoso (A Illa de Arousa. Galicia) a la luz de las últimas intervenciones. In Actualidad de la Investigación Arqueológica en España (2018-2019). Conferencias Impartidas en el Museo Arqueológico Nacional; Prez, A.C., Rodes, C.P., Eds.; Ministerio de Cultura y Deporte: Madrid, Spain, 2020; pp. 159-176.

29. Mañana Borrazás, P. Escavación arqueolóxica da Mámoa 4 de Guidoiro Areoso (A Illa de Arousa. Pontevedra). Ano 2016-2017; Memoria Técnica Inédita; Xunta de Galicia: Santiago de Compostela, Spain, 2017.

30. Prieto Martínez, M.P. Patrones decorativos y ciclos estilísticos de la cerámica prehistórica del noroeste ibérico. Treballs dArqueol. 2019, 23, 63-86. [CrossRef]

31. Prieto Martínez, M.P. Capítulo 35. La alfarería de las comunidades campaniformes en Galicia: Contextos. cronologías y estilo. In Las Comunidades Campaniformes en Galicia. Cambios Sociales en el III y II Milenios BC en el NW de la Península Ibérica; Martínez, M.P.P., Salanova, L., Eds.; Diputación de Pontevedra: Pontevedra, Spain, 2011; pp. 345-361.

32. López Romero, E.; Güimil Fariña, A.; Mañana Borrazás, P.; Otero Vilariño, C.; Prieto Martínez, M.P.; Rey García, J.M.; Vilaseco Vázquez, X.I. Ocupación humana y monumentalidad durante la Prehistoria Reciente en el islote de Guidoiro Areoso (Ría de Arousa. Pontevedra): Investigaciones en el marco de las dinámicas litorales atlánticas actuales. Trab. Prehist. 2015, 72, 353-371. [CrossRef]

33. Castro González, M.G. Cerámica. Producción y Contextos: Guidoiro Areoso. Master's Thesis, Universidade de Santiago de Compostela, Santiago de Compostela, Spain, 2019.

34. Lantes-Suárez, O.; Prieto, B.; Prieto-Martínez, M.P.; Ferro-Vázquez, C.; Martínez-Cortizas, A. The colour of ceramics from Bell Beaker contexts in NW Spain: Relation to elemental composition and mineralogy. J. Archaeol. Sci. 2015, 54, 99-109. [CrossRef]

35. He, Y.; Buch, A.; Szopa, C.; Williams, A.J.; Milan, M.; Guzman, M.; Freissinet, C.; Malespin, C.; Glavin, D.P.; Eigendbrode, J.L.; et al. The search for organic compounds with TMAH thermochemolysis: From Earth analyses to space exploration experiments. Trends Anal. Chem. 2020, 127, 115896. [CrossRef]

36. Rye, O.S. Pottery Technology: Principles and Reconstruction; Taraxacum: Washington, DC, USA, 1981.

37. Nodari, L.; Maritan, L.; Mazzoli, C.; Russo, U. Sandwich structures in the Etruscan-Padan type pottery. Appl. Clay Sci. 2004, 27, 119-128. [CrossRef]

38. Nierop, K.G.J.; Reichart, G.-J.; Veld, H.; Damsté, J.S. The influence of oxygen exposure time on the composition of macromolecular organic matter as revealed by surface sediments on the Murray Ridge (Arabian Sea). Geochim. Cosmochim. Acta 2017, $206,40-56$. [CrossRef]

39. Spaccini, R.; Song, X.; Cozzolino, V.; Piccolo, A. Molecular evaluation of soil organic matter characteristics in three agricultural soils by improved off-line thermochemolysis: The effect of hydrofluoric acid demineralization treatment. Anal. Chim. Acta 2013, 802, 46-55. [CrossRef] [PubMed]

40. Sáiz-Jiménez, C. Production of alkylbenzenes and alkylnaphthalenes upon pyrolysis of unsaturated fatty acids. Naturwissenschaften 1994, 81, 451-453. [CrossRef] 